\title{
Presence of placental lactogen in bovine conceptuses before attachment
}

\author{
A. P. F. Flint, A. Henville and W. B. Christie* \\ A.R.C. Institute of Animal Physiology, Babraham, Cambridge CB2 4AT and *A.R.C. Institute \\ of Animal Physiology, Animal Research Station, 307 Huntingdon Road, Cambridge CB3 OJQ, \\ U.K.
}

\begin{abstract}
Summary. Placental lactogen has been detected by radioreceptor assay in bovine conceptuses collected between 17 and 25 days post coitum, at or shortly after the time of appearance of binucleate cells in the bovine trophectoderm, but before attachment or implantation.
\end{abstract}

\section{Introduction}

Placental lactogen is first detectable in the ovine conceptus on Day 16 of gestation (Martal \& Djiane, 1977), at the time of the appearance of binucleate cells in the trophoblast (Boshier, 1969). This is consistent with the suggestion that ovine placental lactogen is produced by these cells (Martal, Djiane \& Dubois, 1977). However, the process of attachment of the trophoblast to the caruncular epithelium also begins at Day 15 or 16 of gestation in the sheep and the appearance of placental lactogen in the conceptus may be related to this event, rather than to the differentiation of a new cell type. The antiluteolytic action of the embryo is exerted at Day 12 post coitum (Moor \& Rowson, 1966), before the production of placental lactogen.

The cow's placenta also contains a placental lactogen (Forsyth, 1973; Fellows, Bolander, Hurley \& Handwerger, 1976) and, as in the sheep, binucleate cells appear in the bovine trophoblast at about Day 16 of gestation (Greenstein, Murray \& Foley, 1958; Staples, McEntee \& Hansel, 1961). The process of attachment of trophoblast to endometrium, on the other hand, does not begin until the 3rd week of pregnancy in the cow (Amoroso, 1952; Leiser, 1975; Atkinson, King, Carnegie \& Robertson, 1976) and the two events with which the appearance of placental lactogen may be associated are therefore separated by an interval of about 1 week. Embryo transfer experiments suggest that Days 16 and 17 p.c. are also critical for luteal maintenance in early pregnancy (Betteridge, Mitchell, Eaglesome \& Randall, 1976). Production of placental lactogen by bovine trophoblast in vitro has previously been demonstrated at Day 36 of gestation (Buttle \& Forsyth, 1976), but production at earlier stages of pregnancy has not been reported. It was of interest therefore to determine whether placental lactogen was detectable in the bovine conceptus before attachment, both in relation to its possible production by binucleate cells and its role as a putative antiluteolysin.

\section{Materials and Methods}

Conceptuses were obtained by flushing the excised uteri of 11 Hereford $\times$ Friesian cross cows slaughtered between Days 17 and 25 of gestation (oestrus = Day 0 ) after synchronized transfer of 1- or 2-day embryos. The flushing medium was normal saline $(9 \mathrm{~g} \mathrm{NaCl} / 1)$ and the conceptuses were stored frozen at $-15^{\circ} \mathrm{C}$ before analysis. Some of the cattle used had received progesterone as part of a separate study. 
For extraction of placental lactogen, whole conceptuses were either homogenized in the fluid they contained, or with added buffer ( $25 \mathrm{~mm}$-Tris- $\mathrm{HCl}, \mathrm{pH} \mathrm{7.5)}$. In some cases 2 conceptuses obtained from the same cow at 17 days gestation were pooled for extraction, since they are relatively small at this stage (see Table 1 ). The homogenates were centrifuged at $110000 \mathrm{~g}_{\mathrm{av}}$. and the supernatants assayed immediately. A sample of unfractionated homogenate was kept for protein determination by the method of Lowry, Rosebrough, Farr \& Randall (1951). Tissues (heart and liver) used as controls (in which no placental lactogen was expected), and a placental cotyledon from a cow approximately 150 days pregnant, were treated in an identical manner.

Placental lactogen was measured by the radioreceptor assay described by Shiu, Kelly \& Friesen (1973) with the following modifications. In some experiments the yield of unoccupied prolactin receptor in the rabbit mammary tissue used as receptor source was improved by treating the animals (lactating New Zealand White rabbits) with $2 \alpha$-bromocriptine (CB 154; Sandoz Ltd, Basle, Switzerland), $2 \mathrm{ml}$ of a $1 \mathrm{mg} / \mathrm{ml}$ solution being administered 12,24 and $36 \mathrm{~h}$ before death (Durand \& Djiane, 1977). Celite $(0.1 \mathrm{mg})$ was added to each assay tube with the buffer wash in order to stabilize the pellet obtained after centrifuging to separate receptor-bound from free prolactin. With these modifications the assay had the following characteristics: binding in the absence of unlabelled prolactin was $30-50 \%$ (using $0.3 \mathrm{mg}$ protein per assay tube) and non-specific binding was $8-11 \%$. The within- and between-assay coefficients of variation were $8-10 \%$ and $12-15 \%$ respectively, and sensitivity varied between 0.6 and $7 \mathrm{ng}$ prolactin (NIH$\mathrm{S} 9) / \mathrm{ml}$ medium in the assay tube. The affinity constant for the reaction of prolactin with receptor determined by Scatchard analysis was $4.1 \times 10^{9} \mathrm{M}^{-1}$. Values for concentrations of placental lactogen are presented in terms of ovine prolactin equivalents, using NIH-S9 as standard.

\section{Results}

Concentrations of placental lactogen determined in bovine conceptuses obtained between 17 and 25 days post coitum are given in Table 1. Placental lactogen was detectable as early as Day 17 of gestation. Although the mean amount of placental lactogen per conceptus appeared to increase between Day 17 and Days 24-25 (mean contents were $0.33 \mu \mathrm{g}$ and $6.71 \mu \mathrm{g}$ respectively), their protein content increased during this interval, and the concentration of placental lactogen was unchanged (342 ng/mg protein at Day 17 and $467 \mathrm{ng} / \mathrm{mg}$ protein at Days 24-25).

Table 1. Concentrations of placental lactogen in early bovine conceptuses

\begin{tabular}{rccccc}
\hline Sample & $\begin{array}{c}\text { Days post } \\
\text { coitum }\end{array}$ & $\begin{array}{c}\text { No. of } \\
\text { conceptuses } \\
\text { pooled } \\
\text { asplicable }\end{array}$ & $\begin{array}{c}\text { Total } \mu \mathrm{g} \\
\text { placental } \\
\text { lactogen/pooled } \\
\text { material }\end{array}$ & $\begin{array}{c}\text { Total mg } \\
\text { protein/pooled } \\
\text { material }\end{array}$ & $\begin{array}{c}\text { ng placental } \\
\text { lactogen/mg } \\
\text { conceptus } \\
\text { protein }\end{array}$ \\
\hline 1 & 17 & 2 & 0.55 & $11 \cdot 16$ & 49 \\
2 & 17 & 2 & 0.31 & 1.76 & 176 \\
3 & 17 & 1 & $1 \cdot 10$ & 1.37 & 803 \\
4 & 24 & 1 & 1.03 & 14.13 & 73 \\
5 & 24 & 1 & 1.99 & 20.35 & 168 \\
6 & 24 & 1 & 0.76 & 30.00 & 37 \\
7 & 24 & 3 & 17.70 & 48.35 & 590 \\
8 & 24 & 1 & 8.70 & 13.75 & 1054 \\
9 & 25 & 1 & 1.03 & 45.00 & 21 \\
10 & 25 & 1 & 9.70 & 705 \\
11 & 25 & 2 & 49.10 & 1091 \\
\hline
\end{tabular}

Extracts were assayed at a number of dilutions in an attempt to confirm the identity of the placental lactogen measured, and the dilution curves were examined for parallelism with the standard curve. It was not always possible to obtain parallelism over a wide range of dilutions because of the apparent ability of the extracts to precipitate labelled prolactin when they were 
added at high concentrations; however, some degree of parallelism was obtained with all extracts. Text-figure 1 illustrates data for 2 assays. Parallel curves were also obtained with extracts of mid-gestation placenta (about Day 150), which contained 20-25 $\mu$ g placental lactogen $/ \mathrm{g}$ wet wt (approximately $16 \mathrm{ng} / \mathrm{mg}$ protein). No cross-reacting material was present in extracts of heart or liver from either pregnant or non-pregnant cows.

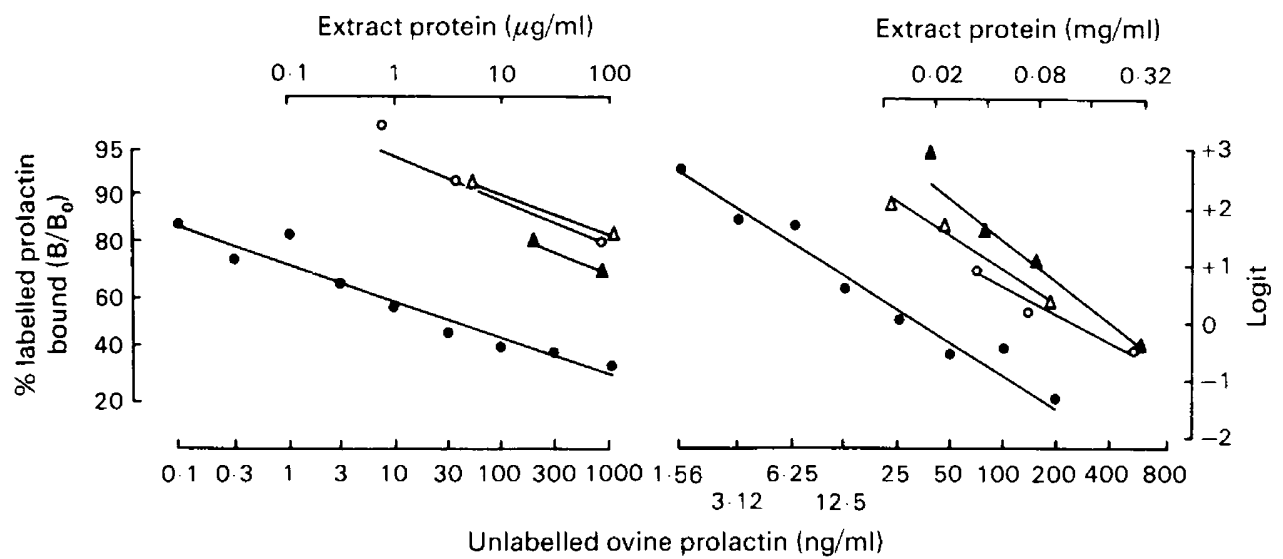

Text-fig. 1. Displacement of ${ }^{125}$ I-labelled ovine prolactin from rabbit mammary receptors by purified ovine prolactin $(\mathbf{O}, \mathrm{NIH}-\mathrm{S} 9)$ and extracts of bovine conceptuses $(0, \Delta, \mathbf{\Delta})$. Results of two separate assays are illustrated.

\section{Discussion}

In view of the parallelism observed between the embryonic extracts and ovine prolactin, and the lack of any cross-reacting material in heart or liver, it seems likely that the radioreceptor assay is measuring bovine placental lactogen. The concentration of placental lactogen measured in midgestation bovine placenta is comparable to that found by Kelly, Tsushima, Shiu \& Friesen (1976), and to the concentration of placental lactogen in mid-gestation ovine placenta (Martal \& Djiane, 1977). Although extracts of a number of tissues not associated with pregnancy contain chorionic gonadotrophin derivatives capable of cross-reacting in radioreceptor and radioimmunoassays for hCG (Yoshimoto, Wolfsen \& Odell, 1977), no such evidence is available for prolactin or placental lactogen. It is difficult to be certain that the material associated with the early conceptus is not maternal prolactin (or some derivative of it) which has become adsorbed to the trophectoderm; however, the fact that no cross-reacting material was found in other tissues suggests that this is not occurring.

The presence of placental lactogen in the early (Day 17) bovine blastocyst is probably related to the appearance of binucleate cells, rather than to the processes of attachment and implantation, which occur later. This may also be true for the appearance of placental lactogen in the ovine conceptus. The production of placental lactogen is the only known endocrine function of these cells (Martal et al., 1977).

The function of placental lactogen at this early stage of gestation is not known; one possibility is that it contributes to the maintenance of the corpora lutea in early pregnancy by reducing uterine production of a luteolysin (i.e. by acting as an antiluteolysin). Embryo transfer experiments suggest that the conceptus must be in the uterus on or before Day 17 for pregnancy to be successful (Betteridge et al., 1976), and this timing is not inconsistent with a role for bovine placental lactogen as an anti-luteolysin. However, experiments with sheep for which oestrous 
cycle length was determined after flushing embryos from the uterus show that the developing conceptus influences luteal function from Day 12 post coitum (Moor \& Rowson, 1966), which is before the appearance of placental lactogen (Martal \& Djiane, 1977) and some 2 days before overt luteal regression begins. Furthermore, the administration of ovine placental lactogen into the uterus has no effect on oestrous cycle length in sheep (Martal \& Djiane, 1977), and whereas ovine placental lactogen is present on Day 25, but not on Days 14 or 15, homogenates of embryos obtained on Day 14 or 15 are effective in preventing luteal regression, while those obtained on Day 25 are not (Rowson \& Moor, 1967). It seems unlikely, therefore, that placental lactogen is the embryonic antiluteolysin in the sheep, and this must cast doubt on any suggestion that it acts in a similar manner in the cow.

We thank Mr K. S. Lindsay for providing some preparations of iodinated prolactin, and Dr R. B. Heap, Dr M. Renfree and Dr D. C. Bulman for reading and commenting on the manuscript. Ovine prolactin was the gift of the National Institutes of Health, Bethesda, U.S.A.

\section{References}

Amoroso, E.C. (1952) Placentation. In Marshall's Physiology of Reproduction, 3rd edn, pp. 127-311. Ed. A. S. Parkes. Longmans, Green \& Co., London.

Atkinson, B., King, G.J., Carnegie, J.A. \& Robertson, H.A. (1976) Relationship between bovine implantation and estrogens produced by the conceptus. Proc. 8th Int. Congr. Anim. Reprod. \& A.I., Krakow 2, 279-281.

Betteridge, K.J., Mitchell, D., Eaglesome, M.D. \& Randall, G.C.B. (1976) Embryo transfer in cattle 10-17 days after estrus. Proc. 8th Int. Congr. Anim. Reprod. \& A.I., Krakow 2, 237-240.

Boshier, D.P. (1969) A histological and histochemical examination of implantation and early placentome formation in sheep. J. Reprod. Fert. 19, 51-61.

Buttle, H.L. \& Forsyth, I.A. (1976) Placental lactogen in the cow. J. Endocr. 68, 141-146.

Durand, P. \& Djiane, J. (1977) Lactogenic activity in the serum of rabbits during pregnancy and early lactation. J. Endocr. 75, 33-42.

Fellows, R.E., Bolander, F.F., Hurley, T.W. \& Handwerger, S. (1976) Isolation and characterization of bovine and ovine placental lactogen. In Growth Hormone and Related Peptides, pp. 315326. Eds A. Pecile \& E. E. Müller.

Forsyth, I.A. (1973) Secretion of a prolactin-like hormone by the placenta in ruminants. In Le Corps Jaune (Colloque de la Société Nationale pour l'Étude de la Stérilité et de Fécondite), pp. 239-255. Eds R. Denamur \& A. Netter. Masson, Paris.

Greenstein, J.S., Murray, R.W. \& Foley, R.C. (1958) Observations on the morphogenesis and histochemistry of the bovine pre-attachment placenta between 16 and 33 days of gestation. Anat. Rec. 132, 321-342.
Kelly, P.A., Tsushima, T., Shiu, R.P.C. \& Friesen, H.G. (1976) Lactogenic and growth hormone-like activities in pregnancy determined by radioreceptor assays. Endocrinology 99, 765-773.

Leiser, R. (1975) Kontaktaufnahme zwischen trophoblast und uterusepithel während der frühen implantation beim rind. Anat. Histol. Embryol. 4, 63-86.

Lowry, O.H., Rosebrough, N.J., Farr, A.L. \& Randall, R.J. (1951) Protein measurement with the Folin phenol reagent. J. biol. Chem. 193, 265-275.

Martal, J. \& Djiane, J. (1977) The production of chorionic somatomammotrophin in sheep. J. Reprod. Fert. 49, 285-289.

Martal, J., Djiane, J. \& Dubois, M.P. (1977) Immunofluorescent localization of ovine placental lactogen. Cell Tiss. Res. 184, 427-433.

Moor, R.M. \& Rowson, L.E.A. (1966) The corpus luteum of the sheep: effect of removal of the embryos on luteal function. J. Endocr. 34, 497502.

Rowson, L.E.A. \& Moor, R.M. (1967) The influence of embryonic tissue homogenate infused into the uterus on the life-span of the corpus luteum in the sheep. $J$. Reprod. Fert. 13, 511-516.

Shiu, R.P.C., Kelly, P.A. \& Friesen, H.G. (1973) Radioreceptor assay for prolactin and other lactogenic hormones. Science, N.Y. 180, 968-971.

Staples, R.E., McEntee, K. \& Hansel, W. (1961) Luteal function as related to pituitary and ovarian cytology and embryo development in the bovine. J. Dairy Sci. 44, 2049-2057.

Yoshimoto, Y., Wolfsen, A.R. \& Odell, W.D. (1977) Human chorionic gonadotropin-like substances in nonendocrine tissues of normal subjects. Science, N.Y. 197, 575-577. 